\title{
Ethnobotanical Survey of Home Gardens in Pandansari and Sumberejo to Support Ecotourism Program in Bromo Tengger Semeru National Park, Indonesia
}

\author{
Widya Kristiyanti Putri ${ }^{1}$, Luchman Hakim², Jati Batoro ${ }^{3}$ \\ Department of Biology, Faculty of Mathematics and Natural Sciences Brawijaya University \\ Veteran Street, Malang 65145, East Java, Indonesia \\ 'widyakp@gmail.com, ${ }^{2}$ luchman@ub.ac.id, ${ }^{3}$ Jati_batoro@yahoo.co.id
}

\begin{abstract}
This research aims to identify plant species diversity in home gardens and describes the numerous aspects related to the land management and types of plan uses which are cultivated in home-garden. Field survey was done in two villages in the periphery forest of Bromo Tengger Semeru National Park (East Java), namely Pandansari dan Sumberejo. The ethnobotanical data were achieved by visiting home gardens, identifying and documenting cultivated plants in home garden, and interviewing respondent through semistructural interview methods. Data was analyzed descriptively FUVs and CSI indices calculation. This study found 186 species (60 family) in Pandasari dan 89 species (46 family) in Sumberejo, representing the important role of home gardens as sites for cultivating valuable plants species. These plants were uses as food, medicinal, ornamental and commercial plants. This ethnobotanical aspect of local people in Pandasari and Sumberejo can integrates into numerous aspects of ecotourism program planning.
\end{abstract}

Keyword: Ecotourism, conservation, rural biodiversity, local wisdoms, home garden

\section{INTRODUCTION}

Tourism in Asia Pacific has contributes significantly in regional development. Tourism in Asia Pacific grows significantly and it is projected to be able to support conservation program in Asia Pacific regions. Tourists arrival in Asia-Pacific reach 263 million with receipt up to 377 US\$ billion [1]. In Indonesia, tourism significantly contributes to the local economic development. In 2014, $8 \%$ of Indonesia's GDP was obtained from tourism. The main attracting resources of Indonesia in the perspectives of domestic and foreign traveler was related the abundance natural and cultural resources. Indonesia has many wildlife sanctuaries and national parks that serve as natural tourism attraction. Indonesia also home of spectacular landscapes with its numerous local culture and traditions.

Recent survey in tourism shows that involving local communities with its attributes is important, and significantly it is becomes the crucial issues in sustainable tourism agenda. The local people should be received impact from tourism business, and their environment can be conserved in order to enhance the destination competitiveness. It is relevant with global mandates to implement sustainable tourism. The sustainable tourism argues that tourism development should be involves three aspects namely economic, environmental and social aspects in balance [2]. Sustainable tourism has been tested in numerous countries in numerous sites, including in rural areas. In rural area, attempt to implement sustainable tourism has been done through optimizing human and its surrounding resources into tourism planning and development.

Optimizing rural resources is the crucial key for sustainable tourism destination. Home gardens as one of the principal component of rural landscapes have significant value in tourism destination sustainability. Home garden is a traditional agro-forestry system where crops cultivated with woody plants species and forming garden like forest $[3,4]$. Home garden is manifestation from indigenous knowledge in manage of surrounding house environment [5]. Home garden has many functions such as source of food $[6,7]$ which area important for poor people. Home gardens are also important in biodiversity conservation. Ethnobotanical survey widely applied to understand plant diversity in home garden, especially plant diversity and structure in perspectives of human culture. Ethnobotany provides significant tools to describe the unique characteristics of local landscapes, known as cultural 
landscapes, which area important in tourism. Ethnobotanical studies of home garden has been conducted in many developing countries in order to collect basis data for rural development The uses of ethnobotanical survey for tourism destination sustainability, however, are rarely implemented.

Pandasari and Sumberejo Villages is two important villages which are located at the buffer zone Bromo Tengger Semeru National Park. Tourism development in these area has been considered important, especially to support biodiversity conservation and increasing local economic revenue among local people in these area. In such villages, home gardens have become the integral part of the human adaptation to live in remotes area in adjacent to national park. The park has been known as one of the famous tourism destination. Therefore, promoting the role of home garden to enhance the performance of both villages as rural tourism destination is important. The objectives of the research were to identify plant species diversity in home gardens and describes the numerous aspects related to the land management and types of plan uses which are cultivated in home garden. Such information is especially important in rural tourism development program.

\section{MATERIALS AND METHODS}

\subsection{Study Sites}

Study areas were located in Pandansari and Sumberejo Villages, Malang District, East Java. Geographically, these villages located on coordinates $08^{\circ} 3^{\prime} 53.3^{\prime \prime} \mathrm{S}, 112^{\circ} 48^{\prime} 28.5^{\prime \prime} \mathrm{E}$ to $08^{\circ} 5^{\prime} 17.4^{\prime \prime} \mathrm{S}$, $112^{\circ} 49^{\prime} 9.4^{\prime \prime} E$. Administratively, Pandansari and Sumberejo are part of Poncokusumo Subdistrict in Malang Regency (Fig.1). Support of the local people in both villages are important in biodiversity conservation in Bromo Tengger Semeru National Park. These villages have fertile soil which has potential for crops production such as corn (Zea mays L.), sugarcane (Saccharum officinarum L.), apple (Malus domestica Borkh.), coffee (Coffea arabica L.), chili (Capsicum frutescens L.), onion (Allium cepa L.), tomato (Solanum lycopersicum L.), and cassava (Manihot esculenta Crantz).

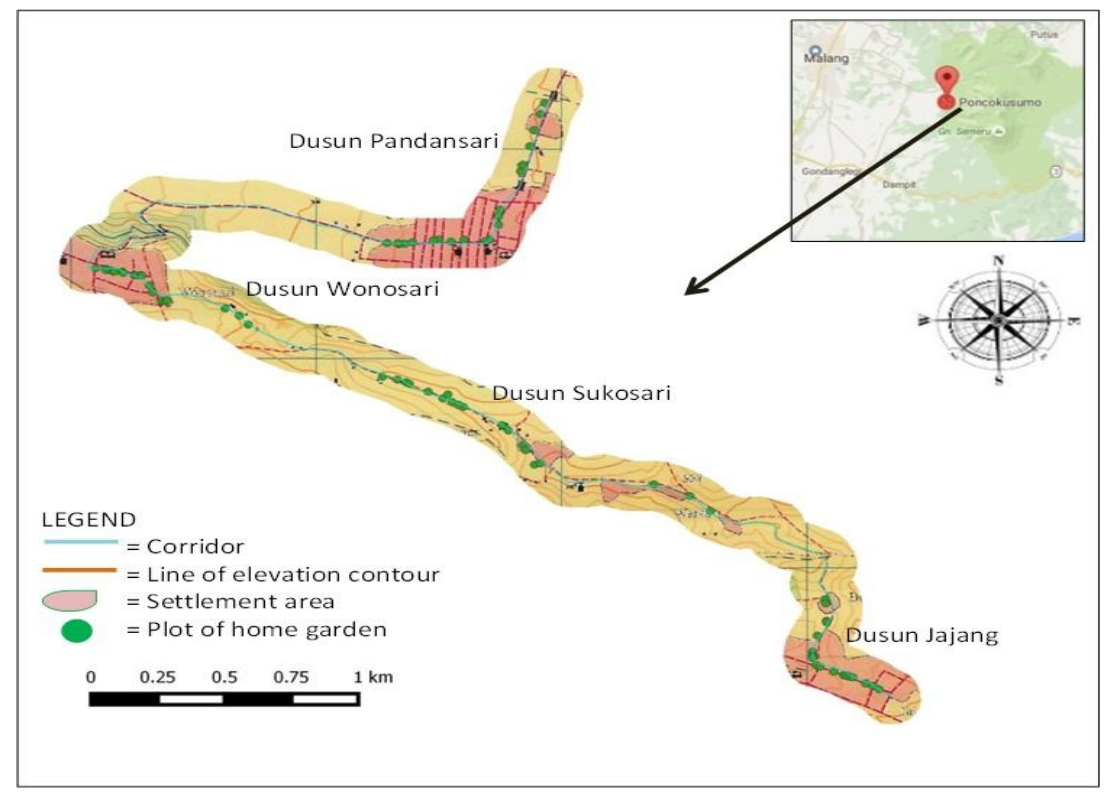

Figure1. Map of Pandansari and Sumberejo Villages

\subsection{Methods}

Home gardens along rural village in Pandasari dan Sumberejo Villages were sampled randomly. About 20 house-home gardens in Pandansari dan 20 house-home garden in Sumberejo was selected for ethnobotanical survey. Totally, there about 40 houses with home gardens were visited. In each house, plants species were observed and described following plants' morphological recognition. In case of plant species unable to identify, some part of the plants organs were collected for further analysis in laboratory. Species names were filed into data sheet. The format of plant species data sheet contain several information such as, local name of species, kind of usage, the importance value of species and other related data. In each visited households, semi structured interviews was implemented. Respondent in this study was includes house hold member with minimal ages about 17 years. In every house hold, one respondent was interviewed about 30-45 minutes using local language (Javanese). 


\subsection{Analysis}

Plant data in data sheet was analyzed and calculated using FUVs (Family Use Values) and CSI (Cultural Significance Index) indices. The Use Values (UVs), FUVs and CSI were calculated using following formula [8]:

$F U V=\frac{\sum F U_{i}}{n}$

$\mathrm{U}_{\mathrm{i}}=$ Amount of plant functions that mentioned by respondent for each family.

$\mathrm{n}=$ Amount of respondents

Higher FUVs means higher importance of a family function in an area for its people.

$C S I=\sum(i \times e \times c) \times C F$

$\mathrm{i}=$ species management. Informing the plant's influence on the daily life of respondent. Value of 2 was given for managed or cultivated species while value of 1 for vice versa.

$\mathrm{e}=$ use preference, the preference given to the use of a species in relation to another. Value 2 for preference species for certain purpose and value 1 for other species that not chosen for same purpose.

$\mathrm{c}=$ use frequency. This considers plants that used effectively by respondent. Value ranges from 2 (known and used plant) to 1 (unknown species or rarely mentioned).

\section{RESULTS AND DisCUSSION}

\section{The home gardens on Pandansari dan Sumberejo}

According to local people in Pandansari dan Sumberejo, home garden is an integral part of family house systems. Principally, home garden is an open area surrounding main house building. Local people organized land for settlement following some patterns (Fig.2). Settlement is consisted of main house, latar, iringan tengen/kiwo and mburitan. Latar is a front side of house that usually used for ornamental plant, bench, drying food crops. In this research, type of plants which found in this side were ornamental plants and crop plants. Iringan tengen (right side) and iringan kiwo (left side) used for crop plant, sometimes ornamental plant, medicinal plant and animal feed plant, temporary storage of crops or firewood. Mburitan is back side of house which filled by big tree plants, fruits plant, crop plants, livestock cage and toilet. This spatial arranging system made home garden plant as ground cover plant so that it could keep soil ecosystem. Shrubs, herbaceous and small tree plants often filled latar and iringan while small and or big trees grew in mburitan. Bio-fence occurs as an integral part of settlements. It is consist of bamboo or tree plants such as Jatropha curcas L., Hibiscus tiliaceus L., Toona sureni (Blume) Merr., Caesalpinia gilliesii (Wallich ex Hook.) Wallich ex D. Dietr and Manihot esculenta Crantz.
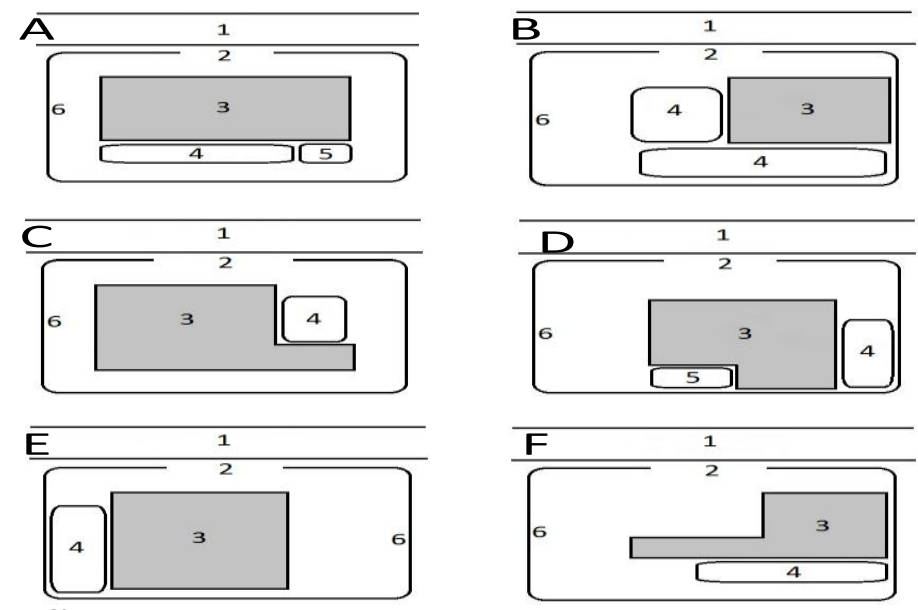

Note:

$\mathbf{2}=$ House gate
$\mathbf{3}=$ Main house

$\begin{aligned} & 4=\text { Animal and livestock cage } \\ & 5\end{aligned}=$ Toilet
$6=$ Fence

Figure2. Space management by local people in Pandansari dan Sumberejo village 
Plant species diversity in home garden was high. This study found 186 species (60 family) in Pandasari dan 89 species (46 family) in Sumberejo. Totally, about 203 plants found in home garden, about 70 plant species found both in Pandansari and Sumberejo Villages. These plants were uses as food, medicinal, ornamental and commercial plants. They were grown at $835 \mathrm{~m}$ to $1005 \mathrm{~m}$ in elevation. From the 203 plants, about 160 plant species were recognized as exotic and 46 native to Malesiana phyto-regions. About 196 was least concern in conservation status. Two vulnerable species were Howea forsteriana Becc. and Pinus merkusii Jungh. \& de Vriese. Species Araucaria angustifolia (Bertol.) Kuntze was considered critically endangered. The remain species were categorized as data deficient.

Plant species in home garden was used for numerous purposes (Table 1), indicated the important aspect of home garden in household live.

Table1. Number of family based on plant use in Pandasari and Sumberejo Villages

\begin{tabular}{|c|c|c|}
\hline Plant Use & Number of Family & Species \\
\hline Food & 29 & 61 \\
\hline Medicine & 12 & 25 \\
\hline Ornamental & 51 & 114 \\
\hline Rites & 4 & 8 \\
\hline Firewood & 2 & 2 \\
\hline Commercial & 28 & 66 \\
\hline
\end{tabular}

\subsection{Plant Usages}

Based on the FUVs calculation, Euphorbiaceae was the highest family with FUVs value (Fig 3). This family has many species that used as ornamental plant, medicinal and food. For example Jatropha multifida L. This species widely used as ornamental plant because its unique leaves. This species also used as medical plant species because its sap can be wound healer like iodine, local people call it as pohon yodium (pohon $=$ tree, yodium $=$ iodine). Manihot esculenta Crantz widely known as food from its tuber and leaves was used as vegetables. Jatropha curcas L. was used for land marking in field. Javanese said jarak pagar (jarak=distance, pagar=fence). This species has medicinal use as stomach ache relief pain by stick it leaves on belly.

Araceae mostly used as ornamental plant because of its beautiful or big leaves. There also Colocasia esculenta (L.) Schott that grown mostly in backyard of home garden or field as food stock.

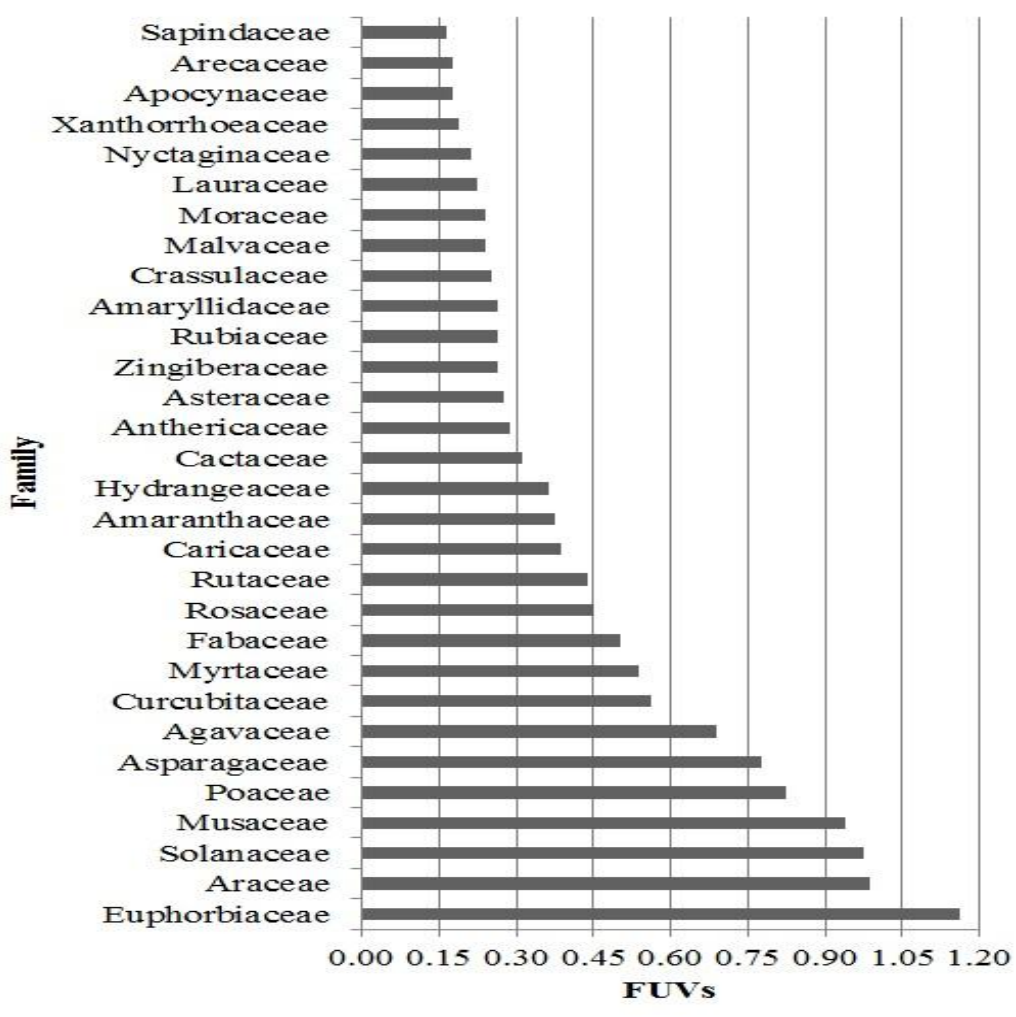

Figure3. Thirty highest FUVs of 65 families 
CSI value represented how a species has a meaningful part of Java culture in Pandansari and Sumberejo Villages (fig. 4). Highest CSI value species was Musa x paradisiaca (AAB group) cv Bungaoisan, locally called pisang candi. It is consumed or sold in the local market. All banana in the field was cultivated without fertilizer. The banana flower was harvested as vegetable. Villagers cultivate banana in mburitan or as barrier from backyard field or neighbouring home gardens. They believed its sap can be wound healing medicine as well as others Musa which reduced glutathione and lipid peroxidation in wound area [9]. Banana leaf usually used as food wrap because its wide shape and believed able to keep food taste better than plastic or paper wraps. The second species with high CSI was chili (Capsicum frutescens L.), locally called lombok or pedesan. This species was cultivated as commercial plant. Chili is important spices in Indonesia's culinary. Capsaicin as one of the capsaicinoid in most Capsicum fruit has responsibility for $90 \%$ of pungency [10]. This fruit has many vitamins such as vitamin A, C, E, Niacin, B6, folic acid and $\mathrm{K}$ as well as minerals $\mathrm{Ca}, \mathrm{Na}, \mathrm{K}, \mathrm{Mg}, \mathrm{Fe}$, $\mathrm{P}, \mathrm{Cu}, \mathrm{Zn}$ and $\mathrm{Co}[11]$.

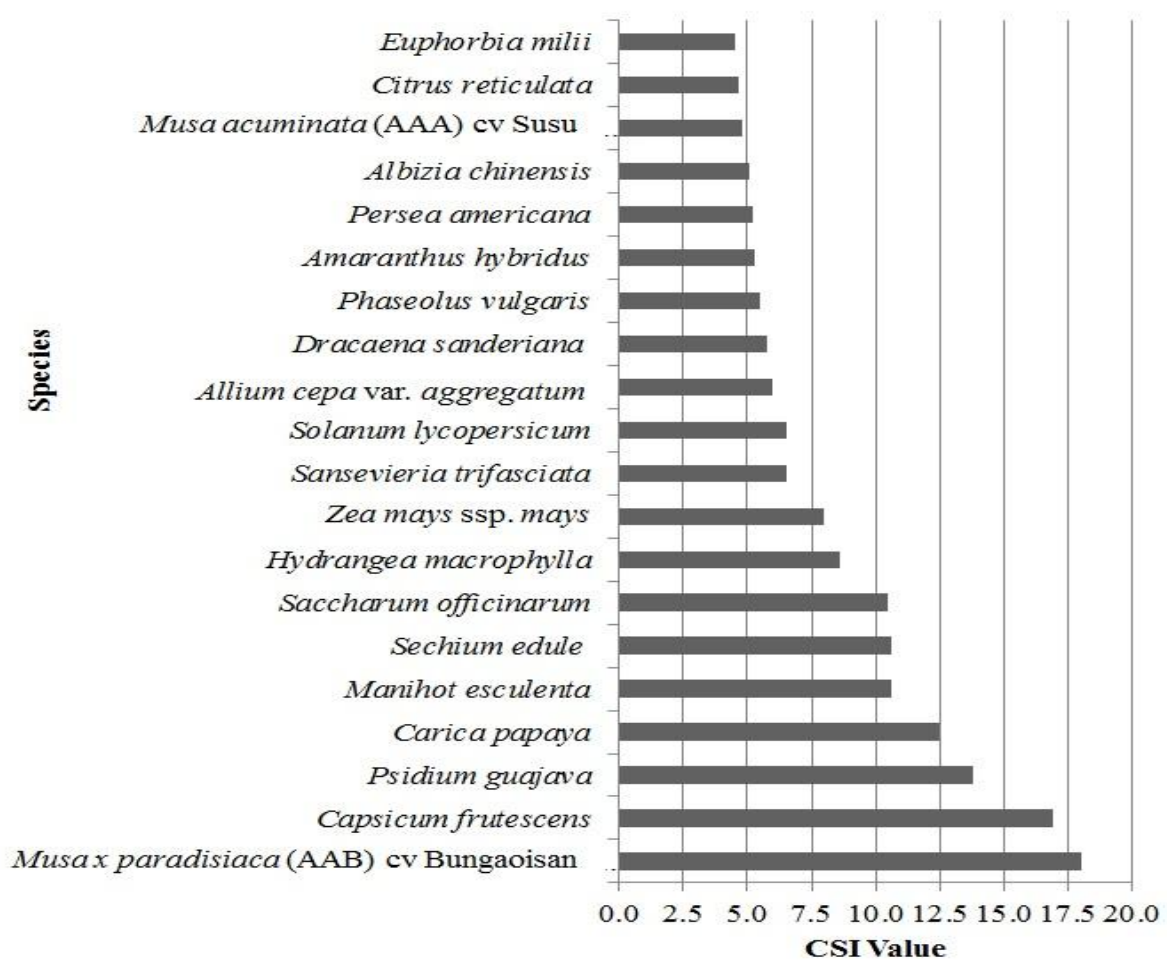

Figure4. Twenty highest CSI value of 203 species

Guava (Psidium guajava L.) planted in latar or iringan of home garden. It is planted as ornamnetal plants. Carica papaya L. widely found in home gardens. The fruit of papaya contain high beta carotene and vitamin C compare to other vitamins [12]. It grow perennially and harvested continously. Although the leaf has bitter taste, it is eaten as vegetable. This plant used as mark or neighbouring barrier in iringan or corner side. Cassava (Manihot esculenta Crantz), locally called pohong, cultivated by people to a a sources of carbohidtrates. Its tuber use as staple food, common in past time until present for some poor area in Java. Tubbers contain starch about 32-35\% in fresh weight and $80-90 \%$ in dry. Its carbohydrate consists of $83 \%$ amylopectin and $17 \%$ amylosa [13]. The leaves was used as vegetable, contain $21-39 \%$ of protein, minerals mainly $\mathrm{Ca}, \mathrm{K}$ and $\mathrm{Mg}$, vitamin $\mathrm{C}$ and phenolic compounds.It was believe by villagers if consumed by mothers could increase breast milk quality, as reported in some African countries by Aregheore in 2012 [14]. This plant survived for long drought and less water condition even without fertilizer and planted as crop plants gap.

\subsection{Implication for Ecotourism Program and Development}

Home gardens in Pandasari and Sumberejo have high content of plant species which area important to support tourism program development on the villages. The conservation of home gardens, especially those located along rural corridor, will contributes to the rural landscape beauty. The ornamental plants which area grows in home garden improve landscapes visual appearance, and therefore able to increase people psychology and mentality. It is especially important in tourism destination planning. 
Abundance fruit plant and vegetable provides opportunities for agricultural product to sell, especially to visitor who visits rural area as tourist. Throughout the world, selling agricultural product to tourist is common. Tourist also interested to buy fresh fruit and vegetable from the field.

The diversity of plant species in houses environment provides opportunities for ecolodge development. Ecolodge is one of the crucial component in ecotourism and urban tourism [15]. Ecolodge provides eco-accommodation which are recommended by ecotourism programs. Ecolodge are often characterized by locality and traditionalism sound of land and vegetation management, as presented by home gardens.

Biodiversity conservation in home gardens should become the crucial aspect in tourism development. In such a case, the empowering program to the local people is important. Focus of the empowering can be addressed to increase local people capacity and awareness to maintain their surrounding land sustainably, including managing home gardens. The constitution of government and stakeholders are important.

\section{Conclusion}

Home gardens in Pandansari and Sumberejo, Malang, rich in term of plant species. This study found 186 species (60 family) in Pandasari dan 89 species (46 family) in Sumberejo, representing the important role of home gardens as sites for cultivating valuable plants species. In home gardens, these plants were uses as food, medicinal, ornamental and commercial plants. These functions can be integrates into rural ecotourism program, especially in ecolodge development.

\section{ACKNOWLEDGMENTS}

We are grateful for cooperation of many respondents in Pandansari and Sumberejo Villages. We also thanks to Dr. Rodiyati Azrianingsih, Dr. Serafinah Indriyani and Mr. Purnomo of Brawijaya University who helped with ethnobiology of Javanese home garden.

\section{REFERENCES}

[1] UNWTO, World Tourism Organization (UNWTO) Annual Report 2014, Impacto Creativo de Comunicación SL, Spain (2015).

[2] WTO and Kementrian Budaya dan Pariwisata Indonesia, Indicators of sustainable development for tourism destinations, Workshop 21-24 March, Lombok (2007).

[3] Gao, Jie, T. He and Q. M. Li, Traditional home-garden conserving genetic diversity: a case study of Acacia pennata in southwest China, Conserv Genet DOI 10.1007/s10592-012-0338-x.@ Springer Science+Business Media B.V (2012).

[4] Saikia, P.,B. I. Choudhury, and M. L. Khan, Floristic composition and plant utilization pattern in homegardens of Upper Assam, India, ISSN 0564-3295, Tropical Ecology, () International Society for Tropical Ecology, 53(1):105-118 (2012).

[5] Solossa, A. H., Soemarno, I. R. Sastrahidayat, and L. Hakim, Home gardens of the local community surrounding Lake Ayamaru, West Papua Province, and its consequences for tourism development and lake conservation, Journal of Biodiversity and Environmental Sciences, ISSN: 2220-6663 (Print) 2222-3045 (Online) Vol. 3, No. 3:1-11 (2013).

[6] Amberber, Mekonnen, M. Argaw, and Z. Asfaw, The role of homegardens for in situ conservation of plant biodiversity in Holeta Town, Oromia National Regional State, Ethiopia, International Journal of Biodiversity and Conservation, Vol. 6(1):8-16 (2013).

[7] Reinhardt, S., Home gardens: treasure troves of biodiversity, Issue Papers People and Biodiv, Deutsche Gesellschaft für Technische Zusammenarbeit (GTZ) GmbH, German (2014).

[8] Silva, V.A.D., L.D.H.C. Andrade, and U.P.D. Albuquerque, Revising the cultural significance index: the case of the Fulni-ô in Northeastern Brazil, Sage Publications, DOI: 10.1177/1525822X05278025, Vol. 18, No. 1:98-108 (2006).

[9] Imam, M. Z. and S. Akter.. Musa paradisiacaL. and Musa sapientum L. : A phytochemical and pharmacological review, Journal of Applied Pharmaceutical Science, ISSN: 2231-3354, 01 (05): 14-20 (2011). 
[10] Rahim, R. and I. Mat, Phytochemical Contents of Capsicum frutescens (Chili Padi), Capsicum Annum (Chili Pepper) and Capsicum Annum (Bell Peper) Aqueous Extracts, International Conference on Biological and Life Sciences. IPCBEE vol.40. IACSIT Press, Singapore (2012).

[11] Emmanuel, C., P. Henry, and O. A. Okiri, Comparative evaluation of the nutritional, phytochemical and microbiological quality of three pepper varieties, Journal of Food and Nutrition Sciences, doi: 10.11648/j.jfns.20140203.15, 2(3): 74-80 (2014).

[12] Nwofia, G. E. and P. Ojimelukwe, Variability in proximate, mineral and vitamin contents of Carica papaya (L.) leaves, fruit pulp and seeds, Int. J. Med. Arom. Plants, ISSN 2249-4340, Vol.2, No.1 pp.90-96 (2012).

[13] Salvador, E. M., V. Steenkamp, and C. M. E. McCrindle, Production, consumption and nutritional value of cassava (Manihot esculenta Crantz) in Mozambique: An Overview. Journal of Agricultural Biotechnology and Sustainable Development, DOI: 10.5897/JABSD2014.0224, ISSN 1996-0186, Vol. 6 (3) pp. 29-38 (2014).

[14] Koubala, B. B., A. Laya, H. Massai, H. Kouninki, and E. N. Nukenine, Physico-chemical Characterization Leaves from Five Genotypes of Cassava (Manihot esculenta Crantz) Consumed in the Far North Region (Cameroon), American Journal of Food Science and Technology, DOI:10.12691/ajfst-3-2-3, Vol. 3 No. 2, 40-47 (2015).

[15] Hakim, L., and Nakagoshi, N, Ecotourism and Climates changes: the ecolodge contribution in global warming mitigation, Journal of Tropical Life Science, 4(1), 26-32 (2014).

\section{AUTHORS' BIOGRAPHY}

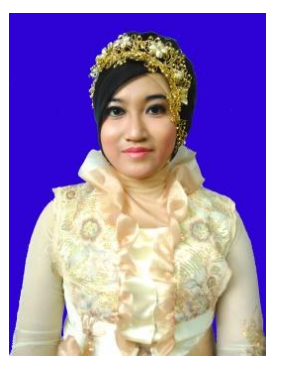

Widya Kristiyanti Putri, born in $11^{\text {th }}$ January, 1989 in Serui Papua. Master student of Department Biology, University of Brawijaya, Malang. Her research focus about ethnobotany of home gardens is part of the Man and The Biosphere Program of Bromo Tengger Semeru Arjuno Biosphere Reserve project under coordinator Dr. Luchman Hakim.

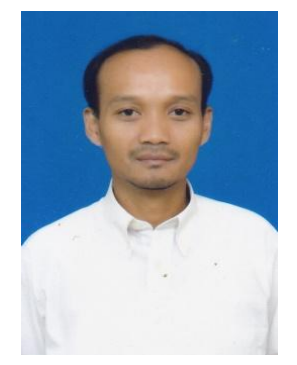

Luchman Hakim, born in Malang (1971). Head of the department of Biology, University of Brawijaya. Research focus about biological conservation and tourism development. He has wrote journals and books related to cultural landscape, conservation, indigenous knowledge and tourism development.

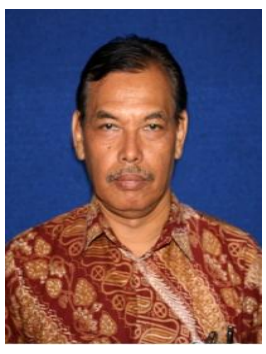

Jati Batoro, born in Yogyakarta (1957) is a lectures in Department Biology, Brawijaya University. Completed Doctoral Degree from IPB at 2012 with the Dissertationrelatedto the Ethnobotany of Tengger people in East Java. Recently he is working in Plant Taxonomy laboratory, Brawijaya University. His research focus on the ethnobotany of Tengger highland in East Java, Indonesia. He has wrote several textbooks in Indonesian related to the ethno-botany and local wisdom. 